\title{
Molecular Mapping of Disease Resistance Genes for Halo Blight, Common Bacterial Blight, and Bean Common Mosaic Virus in a Segregating Population of Common Bean
}

\author{
H.M. Ariyarathne ${ }^{1}$ and D.P. Coyne \\ Department of Horticulture, University of Nebraska, Lincoln, NE 68583 \\ G. Jung and P.W. Skroch ${ }^{2}$ \\ Department of Horticulture, University of Wisconsin, Madison, WI 53706
}

A.K. Vidaver and J.R. Steadman

Department of Plant Pathology, University of Nebraska, Lincoln, NE 68583

P.N. Miklas

U.S. Department of Agriculture, Agricultural Research Service, Prosser, WA 99350

\author{
M.J. Bassett \\ Department of Horticultural Science, University of Florida, Gainesville, FL 32611
}

\begin{abstract}
AdDITIONAL INDEX words. Phaseolus vulgaris, Xanthomonas campestris pv. phaseoli, Pseudomonas syringae pv. phaseolicola,
\end{abstract} linkage mapping, random amplified polymorphic DNA, RAPD, quantitative trait loci

\begin{abstract}
Diseases of beans (Phaseolus vulgaris L.) are primary constraints affecting bean production. Information on tagging and mapping of genes for disease resistance is expected to be useful to breeders. The objectives of this study were to develop a random amplified polymorphic DNA (RAPD) marker linkage map using 78 F9 recombinant inbred (RI) lines derived from a Middle-American common bean cross Great Northern Belneb RR-1 [resistant to common bacterial blight (CBB) and halo blight (HB)] x black A 55 [dominant $I$ gene resistance to bean common mosaic potyvirus] and to map genes or QTL (quantitative trait loci) for resistance to CBB, HB, BCMV (bean common mosaic virus), and BCMNV (bean common mosaic necrosis virus) diseases. The RI lines were evaluated for resistance to leaf and pod reactions to Xanthomonas campestris pv. phaseoli (Xcp) (Smith Dye) strain EK-11, leaf reactions to two Pseudomonas syringae pv. phaseolicola (Psp) (Burkholder) Young et al. (1978) strains HB16 and 83-Sc2A, and BCMV strain US-5 and BCMNV strain NL-3. The linkage map spanned $755 \mathrm{cM}$, including 90 markers consisting of 87 RAPD markers, one sequence characterized amplified region (SCAR), the I gene, and a gene for hypersensitive resistance to $\mathrm{HB} 83-\mathrm{Sc2A}$. These were grouped into 11 linkage groups (LG) corresponding to the 11 linkage groups in the common bean integrated genetic map. A major gene and QTL for leaf resistance to HB were mapped for the first time. Three QTL for leaf reactions to HB16 were found on linkage groups 3, 5, and 10. Four regions on linkage groups $2,4,5$, and 9, were significantly associated with leaf reactions to $\mathrm{HB}$ strain $83-\mathrm{Sc} 2 \mathrm{~A}$. The gene controlling the hypersensitive reaction to HB 83-Sc2A mapped to the same region as the QTL on LG 4. The $I$ locus for resistance to $B C M V$ and $B C M N V$ was mapped to $L G 2$ at about $1.4 \mathrm{cM}$ from RAPD marker A10.1750. Five and four markers were significantly associated with QTL for resistance to CBB in leaves and pods, respectively, with four of them associated with resistance in both plant organs. A marker locus was discovered on LG 10, W10.550, which could account for $44 \%$ and $41 \%$ of the phenotypic variation for CBB resistance in leaves and pods, respectively. QTL for resistance in pod to CBB, leaf resistance to $\mathrm{HB}$, and the I gene were linked on LG 2.
\end{abstract}

Diseases are major constraints to bean yields. Two important bacterial diseases affecting production of common beans (Phaseolus vulgaris, $2 \mathrm{n}=22$ ) in many parts of the world are common bacterial blight (CBB), caused by Xanthomonas campestris pv.

Received for publication 8 June 1998. Accepted for publication 23 July 1999. Published as University of Nebraska, Lincoln, Agricultural Research Division, journal series paper no. 12205. Research was conducted under Title XII Bean/ Cowpea CRSP Project, Univ. of Nebraska, Lincoln, Univ. of Puerto Rico, Mayaguez, Ministry of Agriculture, and Dominican Republic under AID Contract No. DAN 1310-G-SS-6008-00 and also under Projects. 20-036 and 20-042. The authors appreciate assistance of Pat Lambrecht, Department of Plant Pathology, University of Nebraska, Lincoln, for bacterial culture preparations. The cost of publishing this paper was defrayed in part by the payment of page charges. Under postal regulations, this paper therefore must be hereby marked advertisement solely to indicate this fact.

${ }^{1}$ Former graduate student. Current address: Regional Agricultural Research Center, Diyatalawa Road, Bandarawela, Sri Lanka.

${ }^{2}$ Current address: Monsanto Company, 700 Chesterfield Parkway North, St. Louis, MO 63198. phaseoli (Xcp) (Saettler, 1989) and halo blight (HB), caused by Pseudomonas syringae pv. phaseolicola (Psp) (Saettler, 1991; Young et al., 1978). The virus diseases, bean common mosaic virus (BCMV) and bean common mosaic necrotic virus (BCMNV) are also important diseases worldwide (Drijfhout, 1991; McKern et al., 1992).

CBB occurs most widely in beans grown under high temperatures (Saettler, 1989), whereas HB is most severe under moderately low temperatures (Saettler, 1991). There is no satisfactory chemical control for CBB. However, partial control of HB has been reported with copper based sprays (Legard and Schwartz, 1987). Use of resistant cultivars is an effective strategy to manage these diseases. Some bean cultivars/lines resistant to CBB (Coyne and Schuster, 1975, 1983; Park and Dhanvantari, 1994; Saettler, 1989), and HB (Hagedorn and Rand, 1977; Saettler, 1991) have been developed.

Chemical control of many aphid species (Zaumeyer and Thomas, 1957) vectors, and seed certification programs have been 
used to reduce inoculum levels of BCMV and BCMNV. However, genetic resistance is the most effective strategy to control BCMV and BCMNV diseases (Drijfhout, 1978).

The inheritance of resistance to the pathogens causing all these diseases has been widely studied. In the case of CBB, most reports indicate that reaction to $X c p$ in common bean is inherited quantitatively (Coyne and Schuster, 1983; Saettler, 1989). However, Silva et al. (1989) reported the reaction to CBB was simply inherited. Both qualitative and quantitative resistance to $\mathrm{HB}$ has been reported (Taylor et al., 1996). The resistance to BCMV and BCMNV is controlled by major genes, such as the dominant inhibitor $I$ gene, and/or strain-specific recessive $b c$ genes and the strain-nonspecific $b c-u$ gene (Drijfhout, 1978; McKern et al., 1992).

A classical linkage map of common bean was developed using a few morphological markers along with isozyme markers (Bassett, 1991). The map consisted of 47 markers grouped into 13 linkage groups. Molecular genetic linkage maps for common bean have been developed using restriction fragment length polymorphism (RFLP) markers (Nodari et al., 1993a; Vallejos et al., 1992), and random amplified polymorphic DNA (RAPD) markers (AdamBlondon et al., 1994; Jung et al., 1996, 1997). In addition, integrated maps based on RAPD (Skroch, 1998) or RAPD and RFLP markers (Freyre et al., 1998; Vallejos et al., 1999) have been constructed. These maps have been useful for understanding the genetic organization of the common bean genome and identifying marker loci associated with phenotypic traits controlled by a single gene or quantitative trait loci (QTL).

Molecular markers linked to genes controlling resistance to different races of a pathogen or to different pathogens can be used to pyramid the different genes to enhance disease resistance. However, there is only limited information on linkages among genes controlling resistance to different pathogens in common bean so additional research in this area is needed.

The objectives of this study were to construct a genetic linkage map, to identify RAPD markers linked to QTL or genes conferring resistance to $\mathrm{CBB}, \mathrm{HB}$, and $\mathrm{BCMV}$ and $\mathrm{BCMNV}$ (I gene) diseases, and to examine the relationships among genes controlling resistance to these pathogens in a recombinant inbred (RI) population derived from the common bean cross Belneb RR-1 $\mathrm{X}$ A 55. RAPD (Haley et al., 1994) and SCAR markers (Melotto et al., 1996) for the $I$ gene controlling resistance to BCMV and BCMNV in common bean have been reported. In addition, QTL controlling leaf and pod resistance to CBB have been identified (Jung et al., 1996 and 1997; Miklas et al., 1996; Nodari et al., 1993b; Yu et al., 1998). However, there are no published reports of molecular markers linked to QTL for resistance to HB and the linkage relationships between QTL for $\mathrm{CBB}$ and genes for resistance to $\mathrm{HB}$ have not been established.

\section{Materials and Methods}

Plant materials. Seventy-eight F9 recombinant inbred (RI) lines derived from a Middle American common bean cross Belneb RR-1 x A 55 were developed using the single-seed descent breeding method. The white seeded Great Northern Belneb RR-1 breeding line was developed by Stavely et al. (1989). It is resistant to CBB, HB, and to certain strains of BCMV and BCMNV $\left(b c-u, b c-1^{2}\right)$. The black seeded A 55 is susceptible to $\mathrm{CBB}$ and $\mathrm{HB}$ but is resistant to BCMV and BCMNV $(I)$. The RI lines and the parents were grown in a greenhouse, Department of Horticulture, University of Nebraska, Lincoln, and tested for reactions to the pathogens causing $\mathrm{CBB}$ (first trifoliolate leaf and pod) and HB (leaf) diseases, and at Prosser, Wash., for reaction to BCMV and BCMNV. In all experiments, bean seeds were planted in $15-\mathrm{cm}\left(1450-\mathrm{cm}^{3}\right)$ clay pots containing equal parts of sand, sphagnum peatmoss, vermiculite, and Sharpsburg silty clay loam soil. Three seeds were planted per pot and the seedlings were thinned to two plants, 10 days after planting. An extra pot of each parent was planted as a control in each disease screening test by inoculating the plant with the buffer without the particular pathogen. A nutrient solution containing 200 ppm 20N-10P-20K water-soluble fertilizer was applied weekly.

Halo Blight. The experiments were initiated in the greenhouse 6 Jan. 1996, and 10 Feb 1996. The plants were grown at days/nights of $22 \pm 3{ }^{\circ} \mathrm{C}$ (first experiment) and $21 \pm 3{ }^{\circ} \mathrm{C}$ (second experiment), respectively, under a 12 to $14 \mathrm{~h}$ photoperiod, with natural irradiance. Two plants were grown per pot and replicated twice in each of two planting dates using a randomized complete block design (RCBD). The Psp strains HB16 and 83-Sc2A were used for leaf inoculations. The Psp strains were grown on King 's $\mathrm{B}$ medium (King, et al, 1954) for $48 \mathrm{~h}$ at $25^{\circ} \mathrm{C}$. The cultures were transferred gradually to $5 \mathrm{~mL} 12.5 \mathrm{mM}$ potassium phosphate buffer (PB) (pH 7.1) until diluted to read 0.1 O.D. on a Bausch and Lomb Spectronic 20 spectrophotometer (Bausch and Lomb, Rochester, N.Y.) set at $640 \mathrm{~nm}$. By adding a measured bacterial suspension to $\mathrm{PB}$, a final concentration of $1 \times 10^{6}$ colony-forming units $(\mathrm{cfu}) / \mathrm{mL}$ was prepared for inoculation. The lower sides of the 3/4 expanded first trifoliolate leaves of 20-d-old plants were inoculated using the water-soaking inoculation method (Schuster, 1955). Each leaflet of the trifoliolate leaves was inoculated separately with one of the strains. Inoculation occurred within 1 $\mathrm{h}$ after the bacterial suspensions were prepared and kept in a container of ice. Leaf disease reactions were recorded 14 days after inoculation. The rating scale for Psp leaf reactions was as follows: 1 = no visible symptoms, 2 = hypersensitive reaction, 3 = slight water soaking symptoms, $4=$ severe water soaking symptoms, and $5=$ severe water soaking symptoms and systemic chlorosis.

Common bacterial BLight. Experiments were initiated 20 Apr. 1994, and 25 July 1996. The plants were grown at day/night temperatures of $29 \pm 3{ }^{\circ} \mathrm{C} / 23 \pm 3{ }^{\circ} \mathrm{C}$ (first experiment) and $30 \pm$ $3{ }^{\circ} \mathrm{C} / 23 \pm 3{ }^{\circ} \mathrm{C}$ (second experiment) with a $14 \mathrm{~h}$ photoperiod with sun as source of light. A RCBD with two replications (two plants per pot) was used in each experiment. The first trifoliolate leaves were inoculated with $X c p$ strain EK-11 (also designated as V3S8) (Nebraska origin) using the multiple needle method (Andrus, 1948). Pods at the seed filling stage were inoculated with the same strain using the pippettman method (Arnaud-Santana et al., 1994). The inoculation and disease evaluation procedures were similar to those described by Arnaud-Santana et al. (1994). A final concentration of the suspension of $107 \mathrm{cfu} / \mathrm{mL}$ of $X c p$ was used for inoculations within $1 \mathrm{~h}$ after preparation. Necrotic, water-soaking, and chlorotic symptoms developed on the inoculated leaves. Water-soaked areas were visible along the pod suture or along both sides of pod walls 5 to $6 \mathrm{~d}$ after inoculation. Leaf and pod disease reactions were recorded $14 \mathrm{~d}$ after inoculation. The percentage inoculated leaf area with common blight symptoms was recorded. The length of the lesion $(\mathrm{mm})$ from the site of inoculation on the pod was measured $7 \mathrm{~d}$ after inoculation.

BEAN COMMON MOSAIC AND NECROSIS VIRUSES. Two virus tests were conducted in Prosser, Wash., on 11 May 1996 and 7 Nov. 1996, respectively. In each test, three plants per RI line in a 10$\mathrm{cm}\left(1000-\mathrm{cm}^{3}\right)$ pot containing $750 \mathrm{~mL}$ of artificial soil medium 
(Sunshine Mix No 1, Fision Hort., Vancouver, B.C., Canada) were grown in the greenhouse. A volume of $200 \mathrm{~mL}$ of $20 \mathrm{~N}-20 \mathrm{P}-$ $20 \mathrm{~K}$ liquid fertilizer was applied once to each pot at $14 \mathrm{~d}$. Sevenday-old seedlings were inoculated with NL-3 BCMNV strain in the first test and US-5 BCMV strain in the second test using the rub inoculation method (Haley et al., 1994). The strain NL-3 (pathogroup VI) induces top necrosis on plants with unprotected $I$ gene, and vein necrosis on plants with protected $I, b c-I^{2}$. Disease reactions were recorded $7,14,21$, and $28 \mathrm{~d}$ after inoculation. The plants were grown under days/nights of $27{ }^{\circ} \mathrm{C}$ and $20^{\circ} \mathrm{C}$ day/ night, respectively, and a 15 -h photoperiod, with sun as the light source. The US-5 strain (pathogroup IV) induces mosaic symptoms on plants with recessive $i i$, such as $i i, b c-u, b c-1^{2}$.

DNA EXTRACTIONs. Total genomic DNA extractions were prepared from fresh trifoliolate leaves of RI lines and the parents using the method of Skroch and Nienhuis (1995).

RAPD MARKERS. RAPD primers from Operon (Operon Technologies, Alameda, Calif.) and University of British Columbia (Vancouver, B.C. Canada) were selected based on the information from RAPD markers mapped previously in different populations (Freyre et al., 1998; Jung et al., 1996 and 1997; Skroch, 1998; Vallejos et al., 1999). Seventy primers with a high polymorphism rate between the parents and two sequence characterized amplified region (SCAR) markers, SW13 and BC409SCAR, linked to the $I$ gene (Melotto et al., 1996) and QTL for CBB resistance (Jung et al., 1999), respectively, were used to generate marker data. For the SCAR marker SW13, PCR conditions were the same as for RAPD markers except two primers were used together for the reaction. PCR conditions for the SCAR marker BC409SCAR were described in Jung et al. (1999). For RAPD reactions, PCR procedures were as described by Johns et al. (1997) modified from Skroch and Nienhuis (1995). The average number of polymorphic markers per primer was 2.5. A 100-base pair ladder (Gibco BRL, Life Technologies, Rockville, Md.) was used as a size marker to estimate the length of RAPD bands on an agarose gel. Markers were designated by the letter identifying the Operon kit or the University of British Columbia kit (BC), the number of the primer, and the approximate length in base pairs. Based on gel pictures for mapping data and parental screens, the marker nomenclature used here was reconciled with that used in previous studies (Freyre et al., 1998; Jung et al., 1996,1997; Skroch, 1998; Vallejos et al., 1999). Thus, RAPD markers placed on the linkage map used in this study correspond to RAPD markers having the same name in these other studies. For easy reference to the integrated linkage maps, linkage groups were identified as 1 to 11 corresponding to linkage groups B1 to B11 of Freyre et al. (1998), as well as A to K, corresponding to the linkage group names used by Vallejos et al. (1999).

Statistical analysis. The chi-square test was used to test the marker segregation data for goodness-of-fit to a 1:1 ratio to detect distortion of markers. A genetic linkage map was constructed using MAPMAKER Macintosh version 2.0 (Lander et al., 1987). Linkage groups were established initially based on a logarithm of odds (LOD) score of 3.0 and a linkage threshold of 0.4 using the Group command. Linkage groups were built by first selecting a subset of markers based on LOD scores and pairwise linkages. Linkage order in these small sets was tested using the Compare command. Subsequently additional markers were added using the Try command. All markers were placed on the ordered linkage map for which there was at least a 2.0 difference in LOD scores for the most likely and second most likely position for that marker. Finally, the marker order was checked with the Ripple command. Map distances (centiMorgan, cM) were estimated using recombination fractions and Kosambi's mapping function (Kosambi, 1944) between ordered marker loci. The collinearity of RAPD linkage maps in different populations (Skroch 1998; Vallejos et al., 1999), and the mapping of markers herein that had been mapped previously relative to RFLP markers (Freyre et al., 1998; Vallejos et al., 1999) allowed us to establish relationships between the linkage groups identified and linkage maps described previously. Linkage group names were then assigned corresponding to those in the integrated common bean genetic map.

The mean phenotypic disease reactions of lines from both experiments for each trait were used to estimate gene or QTL locations for each trait. In addition, $\mathrm{F}$ tests for single-factor analysis of variance (ANOVA) for each pairwise marker locustrait comparison were used to determine if significant variation in trait expression was associated with differences in marker-locus genotypic classes. Markers showing a significant association with resistance $(P<0.05)$ based on single factor ANOVA were entered into a stepwise regression analysis to find the best multilocus model for each trait. For each linkage group, the marker locus with the most significant association with the trait was assumed to be the most likely position of the QTL and this marker was entered into the multiple regression analysis. The hypothesis of additive $\times$ additive epistasis between independent QTL was tested using SAS PROC GLM (SAS Inst. Inc., SAS, 1982).

The method of interval mapping with MAPMAKER-QTL 2.0 (Lander and Botstein, 1989) was also used for localization of QTL and for estimation of their genetic effects. Interval mapping results were typically very similar to the results of the single factor ANOVA in determining the most likely position of detected QTL. Thus, results of the interval mapping analysis are only reported when they contribute significantly in refining the relative position of QTL with respect to flanking markers. For the purpose of reporting linkage orientation, RAPD markers amplified from the same parent that contributed an associated (linked) phenotypic effect were considered linked in coupling phase with the corresponding QTL or gene locus.

\section{Results and Discussion}

RAPD MARKER SEGREGATION. Of the 170 RAPD markers scored, $135(80 \%)$ fit the expected 1:1 ratio based on the chi-square goodness-of-fit test (not presented). The SCAR marker (originally designated as SW 130) for the $I$ gene for resistance to BCMV (Melotto et al., 1996) showed a deviation from the expected $1: 1$ ratio $(\chi 2=13.5, \mathrm{df}=1, P<0.01)$ in our population. In linkage group 10, six out of 10 mapped markers were distorted (Fig. 1). In a previous study we also observed high segregation distortion in a recombinant inbred population (31\%) (Jung et al., 1997). However, in the present study as well as in previous studies (Jung et al., 1996, 1997) we have observed that distorted segregation was specific to certain regions of the genetic map. Groups of linked markers show similar patterns of segregation distortion making it unlikely that the RAPD technology itself is to blame. Lower percentages of segregation distortion have been observed previously (9\% and 8\%) (Nodari et al., 1993a; Vallejos et al., 1992) in studies based on F2 or backcross progeny. However, if segregation distortion is due to genetic drift and selection during generations of inbreeding, recombinant inbred populations would be expected to show greater percentages of distorted markers 


\section{1-H}

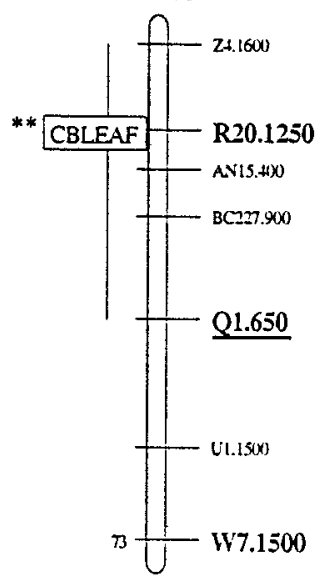

5-E
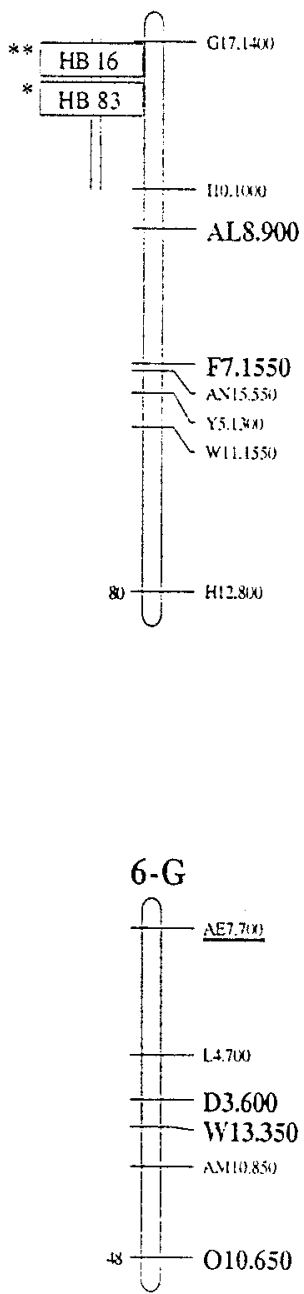

2-D

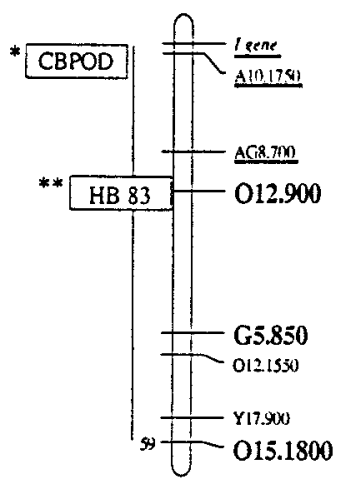

7-A
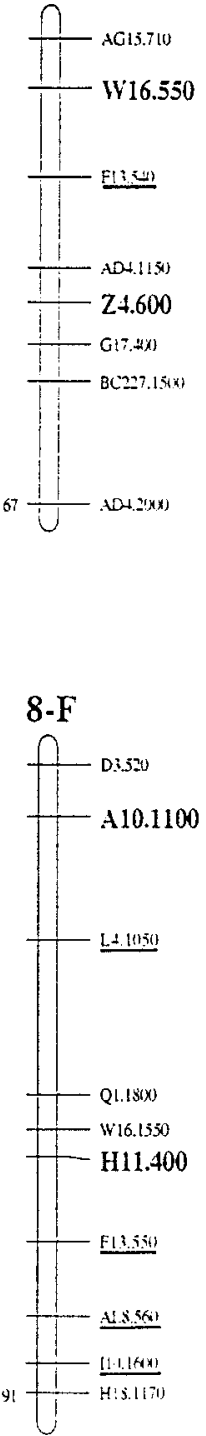

3-C
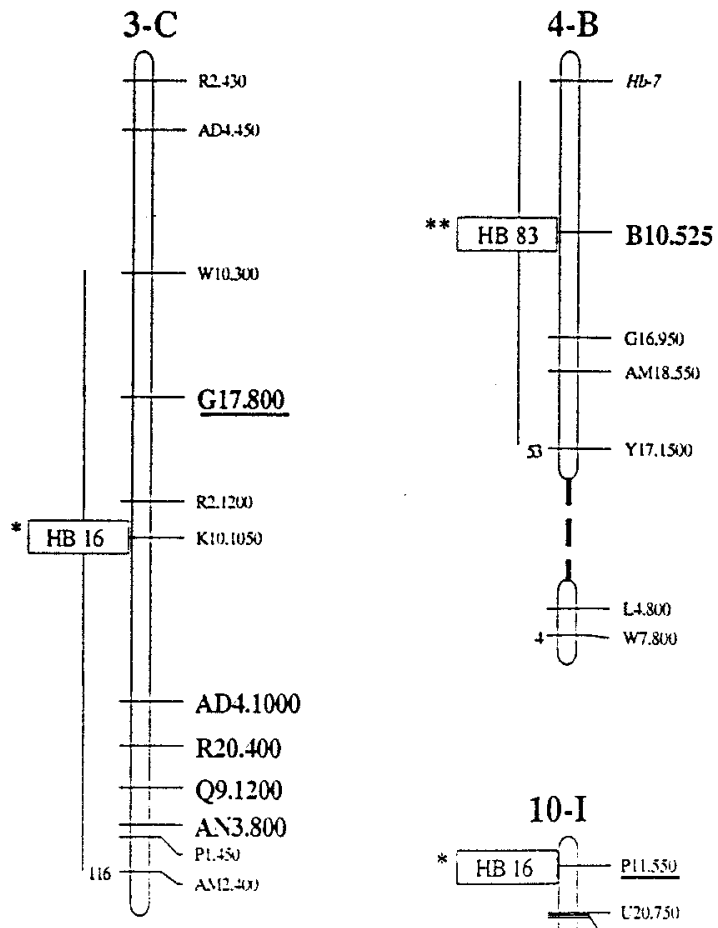

10-I

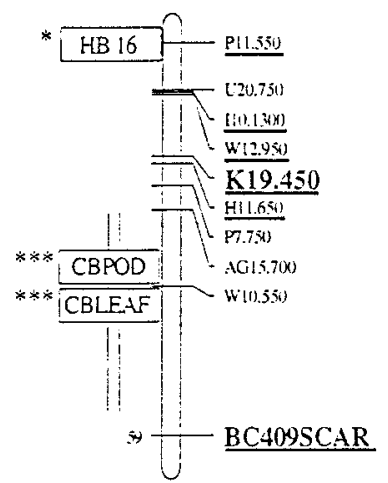

9.K

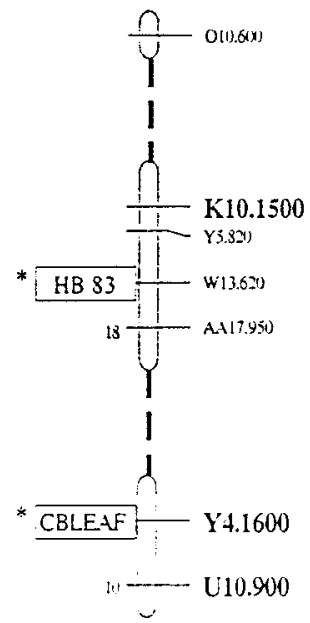

11-J

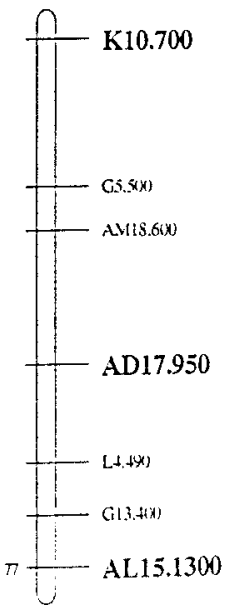

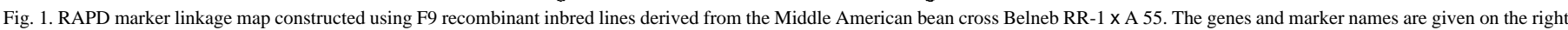

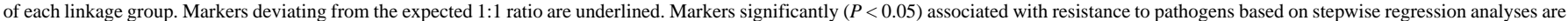
indicated by boxes located on the left of each linkage group. CBLEAF and CBPOD indicate QTL for resistance to common bacterial blight strain EK-11 in first trifoliolate leaves and pods, respectively.

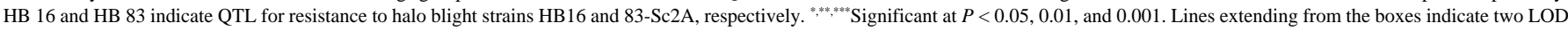
confidence interval from the most likely position of the QTL detected by interval mapping. BC409SCAR indicates a SCAR marker based on the RAPD marker BC409.1250 (Jung et al., 1999). RAPD marker loci previously identified in the integrated bean genetic map (Freyre et al., 1998; Vallejos et al., 1999) are indicated in larger bold font. For linkage groups 4 , and 10 the indicated marker loci

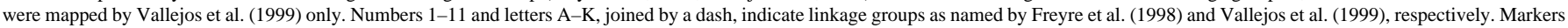
Q1.650 and W7.1500 were named Q1.600 and W1.1450 in Freyre et al. (1998). 
because of the greater numbers of generations the populations have to be advanced. However, high segregation distortions have been reported in many mapping populations regardless of marker types, generations, and crops.

LINKAGE MAP CONSTRUCTION. The 174 markers (170 RAPD markers and two SCARs, and two phenotypic markers) were grouped into 11 linkage groups (LG). Of these, 90 could be placed on the ordered linkage map with LOD 2.0 confidence and were used for the subsequent statistical analysis. In addition to RAPD marker loci, the I gene, the SCAR marker (BC409SCAR) associated with $\mathrm{CBB}$ resistance (Jung et al., 1999), and the $\mathrm{Hb}$-7 locus for the hypersensitive reactions to $\mathrm{HB}$ strain $83-\mathrm{Sc} 2 \mathrm{~A}$, were included the linkage map (Fig. 1). In this study, we wanted to make use of previous mapping information to achieve better genome coverage and to allow the future integration of the results from the present study with the results of previous and future mapping studies. In order to achieve this we deliberately picked primers that amplified previously mapped markers dispersed throughout the common bean genome. The resulting linkage map, spanning $755 \mathrm{cM}$, is longer than several previously reported common bean linkage maps based on RAPD markers (AdamBlondon et al., 1994; Jung et al., 1996, 1997), nearly the same as one other RAPD map that was based on $50 \%$ more markers (Skroch 1998; Vallejos et al., 1999), but smaller than the integrated RAPD and RFLP maps reported by Freyre et al. (1998) and Vallejos et al. (1999).

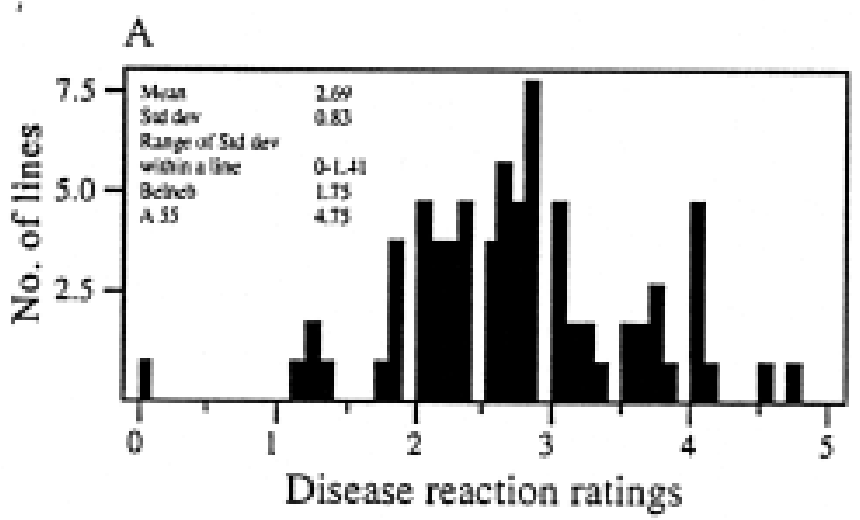

The locations of previously mapped markers were compared to the integrated maps of Freyre et al. (1998) and Vallejos et al. (1999). Based on this comparison it was possible to determine the identity and a rough alignment relative to the integrated map for 9 of the 11 linkage groups identified in the present study. The orientation of linkage groups 4 and 9 was problematic because of the large gaps and small number of markers in these linkage groups. Through comparison of linkage group 9 to the integrated RAPD map of Skroch (1998), in addition to unambiguously joining sections of the map falling below the linkage significance threshold, it was also possible to determine the overall orientation of the map. However, the orientation of the four markers in the middle of the map, including marker W13.620 significantly associated with resistance to $\mathrm{HB}$, could not be determined relative to the ends of the linkage group. Linkage group 4 was identified by four common markers including the linked pair L04.800W07.800, but the orientation relative to the integrated map could not be determined.

BCMV AND BCMNV ReSistance Locus. The dominant $I$ gene provides an immune or temperature-dependent necrotic reaction to BCMV strains and a temperature-independent resistant reaction (black root) to necrotic BCMNV strains (Drijfhout, 1978; McKern et al., 1992; Mink et al., 1994). Even though there was not a good fit to a 1:1 ratio of resistant (57) and susceptible (14) $\left(\chi^{2}=26.04,1 \mathrm{df}, P<0.001\right)$ RI lines to BCMNV determined by the $I$ gene, this locus was mapped with other distorted RAPD markers. The $I$ locus mapped to LG 2 about $1.4 \mathrm{cM}$ from marker

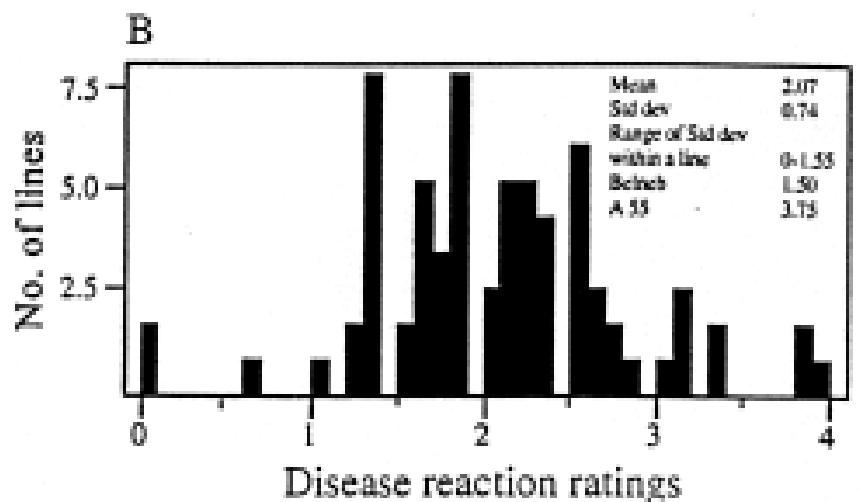

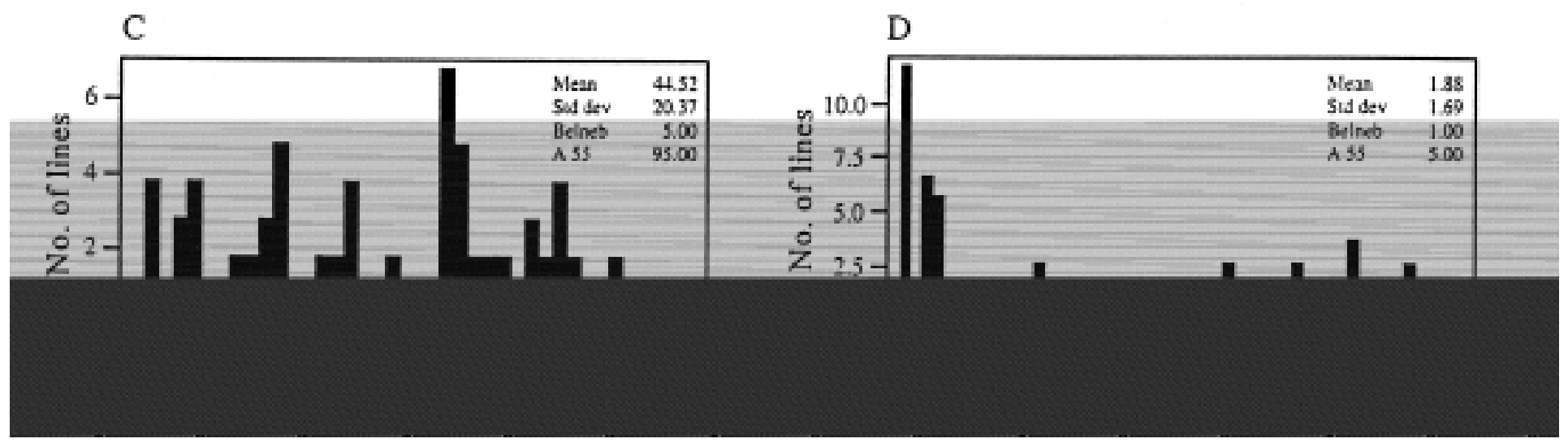

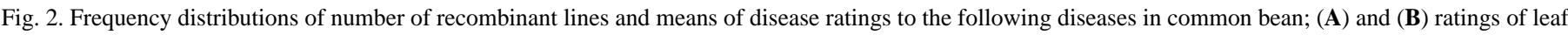
reactions to halo blight $(\mathrm{HB})$ strains $\mathrm{HB} 16$ and $83-\mathrm{Sc} 2 \mathrm{~A}$, respectively, using a rating scale $1=$ no visible symptoms, $2=$ hypersensitive reaction, $3=$ slight water

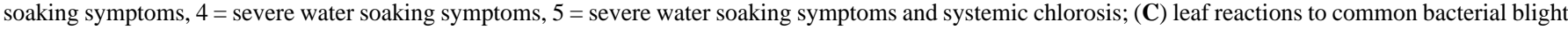

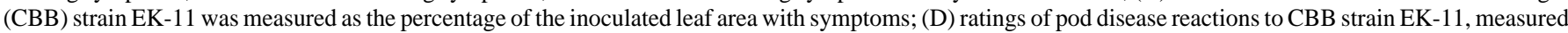
as the length $(\mathrm{mm})$ of water-soaked region from the site of pod inoculation. 
Table 1. Summary of the single-factor ANOVA and stepwise regression analyses of RAPD molecular marker and phenotypic data for detection of QTLs associated with leaf resistance to halo blight (HB) strains HB16 and 83-Sc2A in a recombinant inbred line population derived from a common bean cross Belneb RR-1 (resistant) x A 55 (susceptible).

\begin{tabular}{|c|c|c|c|c|c|c|c|}
\hline \multirow[b]{2}{*}{ HB strain } & \multirow[b]{2}{*}{ Marker $^{y}$} & \multirow{2}{*}{$\begin{array}{c}\text { Linkage } \\
\text { phase }\end{array}$} & \multicolumn{2}{|c|}{ Single-factor ANOVA ${ }^{z}$} & \multicolumn{2}{|c|}{ Stepwise regression $^{z}$} & \multirow{2}{*}{$\begin{array}{l}\text { Linkage } \\
\text { group }^{\mathrm{x}}\end{array}$} \\
\hline & & & $P>\mathrm{F}$ & $R^{2}$ & $P>\mathrm{F}$ & $\overline{R^{2}}$ & \\
\hline \multirow[t]{4}{*}{ HB16 } & G17.1400 & Coupling & 0.0022 & 12 & 0.0001 & 20 & 5 \\
\hline & K10.1050 & Coupling & 0.0195 & 7 & 0.0054 & 8 & 3 \\
\hline & P11.550 & Coupling & 0.0498 & 5 & 0.0056 & 8 & 10 \\
\hline & Cumulative $R^{2}$ & & & & & 36 & \\
\hline \multirow[t]{6}{*}{$83-\mathrm{Sc} 2 \mathrm{~A}$} & B10.520 & Coupling & 0.0012 & 13 & 0.0013 & 13 & 4 \\
\hline & O12.900 & Repulsion & 0.0027 & 11 & 0.0025 & 10 & 2 \\
\hline & W13.620 & Coupling & 0.0363 & 6 & 0.0334 & 5 & 9 \\
\hline & G17.1400 & Coupling & 0.0402 & 5 & 0.0464 & 4 & 5 \\
\hline & W13.350 & Coupling & 0.0361 & 6 & & & 6 \\
\hline & Cumulative $R^{2}$ & & & & & 32 & \\
\hline
\end{tabular}

${ }^{\mathrm{z}}$ Significant levels determined for $\mathrm{F}$ tests based on single-factor ANOVA or stepwise regression analysis and percentage of phenotypic variation explained by the marker based on ANOVA or stepwise regression analysis.

${ }^{\mathrm{y}}$ Marker significantly associated with a trait.

${ }^{x}$ The assigned number for the group of markers with linkages as defined in Fig. 1.

A10.1750 consistent with the previous mapping of the I gene in the RFLP map of common bean (Nodari et al., 1993a). Recently, a RAPD linked to the $I$ gene was converted to a sequence specific PCR marker by Melotto et al. (1996). This marker, SW13, was 1 $\pm 0.7 \mathrm{cM}$ and $5 \pm 2 \mathrm{cM}$ distant from the $I$ gene locus in two populations, 'Seafarer' x 'UI-114' and G91201 x 'Alpine', respectively (Melotto et al., 1996). However, in our population the linkage distance between SW13 and the $I$ gene was about 8.9 $\mathrm{cM}$. These differences could arise from greater recombination (crossing over) in our population compared to the previously studied populations. Such large differences are observed commonly. Indeed, a 5-fold difference in recombination frequency between SW13 and the $I$ gene was observed by Melotto et al. (1996).

In spite of the significant distortion from the expected ratio, the linkage of the $I$ gene to SW13 was still detected. Markers in this region of the map were also distorted confirming the distortion found in the phenotypic data was not due to errors in collecting the phenotypic data. The $I$ gene is used widely to provide effective resistance to $\mathrm{BCMV}$ and $\mathrm{BCMNV}$ in major commercial common bean cultivars. Although there appears to be more recombination than thought between the previously identified SW13 marker and the $I$ gene, marker A10.1750, found to be tightly linked in this population might be useful for marker assisted selection and should be tested further.

QTL FOR HB RESISTANCE. Quantitative (Taylor et al., 1996; Velich et al., 1994) and qualitative inheritance (Coyne and Schuster, 1975; Taylor et al., 1996) for reaction to Psp have been reported previously. In the present study a hypersensitive reaction was observed on leaves of the parent Belneb RR-1 for both HB strains, while parent A 55 expressed high and uniform susceptibility to both HB strains. A number of RI lines showed a hypersensitive reaction to both $\mathrm{HB}$ strains while the remaining RI lines ranged from slight compatibility to high compatibility (Fig. 2). Breeders are interested in using genes that give partial resistance based on low compatibility of the host and pathogen as well as genes conferring the hypersensitive reaction, a specific type of incompatibility. Examination of our phenotypic data suggested

Table 2. Summary of the single-factor ANOVA and stepwise regression analyses of RAPD molecular marker and phenotypic data for detection of QTLs associated with first trifoliolate leaf and pod resistance to common bacterial blight (CBB) strain EK-11 in a recombinant inbred line population derived from a common bean cross Belneb RR-1 (resistant) X A 55 (susceptible).

\begin{tabular}{|c|c|c|c|c|c|c|c|}
\hline \multirow[b]{2}{*}{ Plant organ } & \multirow[b]{2}{*}{ Marker $^{y}$} & \multirow[b]{2}{*}{ Linkage phase } & \multicolumn{2}{|c|}{ Single-factor ANOVA ${ }^{\mathrm{z}}$} & \multicolumn{2}{|c|}{ Stepwise regression $^{z}$} & \multirow[b]{2}{*}{ Linkage group ${ }^{x}$} \\
\hline & & & $P>\mathrm{F}$ & $R^{2}$ & $P>\mathrm{F}$ & $R^{2}$ & \\
\hline \multirow[t]{6}{*}{ First trifoliolate leaf } & W10.550 & Coupling & 0.0000 & 36 & 0.0000 & 44 & 10 \\
\hline & $\mathrm{R} 20.1250$ & Coupling & 0.0025 & 12 & 0.0024 & 7 & 1 \\
\hline & Y4.1700 & Repulsion & 0.0146 & 8 & 0.0243 & 3 & 9 \\
\hline & G17.400 & Repulsion & 0.0397 & 6 & & & 7 \\
\hline & A10.1750 & Coupling & 0.0331 & 6 & & & 2 \\
\hline & Cumulative $R^{2}$ & & & & & 54 & \\
\hline \multirow[t]{5}{*}{ Pod } & W10.550 & Coupling & 0.0000 & 37 & 0.0000 & 41 & 10 \\
\hline & A 10.1750 & Coupling & 0.0159 & 7 & 0.0432 & 3 & 2 \\
\hline & G17.400 & Repulsion & 0.0081 & 9 & & & 7 \\
\hline & $\mathrm{R} 20.1250$ & Coupling & 0.0314 & 6 & & & 1 \\
\hline & Cumulative $R^{2}$ & & & & & 44 & \\
\hline
\end{tabular}

${ }^{\mathrm{z}}$ Significant levels determined for $\mathrm{F}$ tests based on single-factor ANOVA or stepwise regression analysis and percentage of phenotypic variation explained by the marker based on single-factor ANOVA or stepwise regression analysis.

${ }^{\mathrm{y}}$ Marker significantly associated with a trait.

xThe assigned number for the group of markers with linkages as defined in Fig. 1. 
that the BA population was segregating for genes responsible for the hypersensitive reaction as well as genes for partial resistance not related to the hypersensitive reaction.

Lines were classified initially based on the presence or absence of the hypersensitive response. For HB 16, chi-square tests indicated a good fit to a $3(64 \mathrm{~S}): 1(14 \mathrm{R})$ ratio $\left(\chi^{2}=2.08,1 \mathrm{df}\right.$, $P>0.15)$ or a $7(64 \mathrm{~S}): 1(14 \mathrm{R})$ ratio $\left(\chi^{2}=2.11,1 \mathrm{df}, P>0.45\right)$ suggesting that either two or three major genes were involved in determining primarily the reactions to HB16 strain. In the case of the leaf reaction to HB strain 83-Sc2A, a good fit to a 1 (39S) : 1 (36R) ratio $\left(\chi^{2}=0.12,1 \mathrm{df}, P>0.73\right)$ was detected indicating that a single gene was mainly involved in determining the hypersensitive reaction. Since segregation of the hypersensitive response in the BA population did not fit a 1:1 segregation ratio, the phenotypic data were analyzed for strain HB16 as a quantitative trait only. However, the data for strain $83-S c 2 A$ were analyzed first by classifying each line for the presence or absence of the hypersensitive response and identifying a single locus associated with this effect. Subsequently, the phenotypic data for HB 83$\mathrm{Sc} 2 \mathrm{~A}$ were combined with the marker segregation data in a traditional QTL analysis and the results compared with the first approach.

For the hypersensitive response to $\mathrm{HB} 83-\mathrm{Sc} 2 \mathrm{~A}$, a single locus was identified, by classifying BA lines, on LG 4 (Fig. 1). When a QTL analysis was done based on compatibility ratings, taking the means over replications and experiments, five chromosomal regions were significantly $(P<0.05)$ associated with leaf resistance to HB strain 83-Sc2A based on single-factor ANOVA. For leaf resistance to $\mathrm{HB}$ strain $83-\mathrm{Sc} 2 \mathrm{~A}$, four QTL were found in linkage groups 2, 4, 5, and 9, respectively, and accounted for 32\% of the total phenotypic variation for the trait (Table 1) (Fig. 1). The single gene controlling the hypersensitive reaction to $\mathrm{HB} 83$ $\mathrm{Sc} 2 \mathrm{~A}$ detected using chi-square analysis was mapped in an interval $21.6 \mathrm{cM}$ from RAPD marker B10.520 in LG 4, which was significantly associated with the QTL for resistance based on single-factor ANOVA (Fig. 1). In addition, the interval mapping approach indicated a LOD 2.0 confidence interval that included the locus for the hypersensitive reaction to strain $\mathrm{HB}$ 83-Sc2A (Fig. 1). Thus, it is likely that the identified QTL and the single gene suggested for the hypersensitive response represent the same locus. The gene for hypersensitive reaction to the HB strain 83-Sc2A was tentatively symbolized as a $\mathrm{Hb}-7$ because the strain was identified as a race 7 based on the reaction on the eight differential cultivars and 29 HB strains (Ariyarathne, 1997).

Three QTL associated with markers G17.1400 (LG 5), K10.1050 (LG 3), and P11.550 (LG 10) for leaf resistance to HB16 were found by stepwise regression accounting for $20 \%$, $8 \%$, and $8 \%$, respectively, of the phenotypic variation for the trait (Table 1; Fig. 1). This result agrees fairly well with the hypothesis of two or three major genes controlling the reaction based on the chi-square analysis of the phenotypic data for number of lines with hypersensitive and compatible reactions.

Significant effects for HB resistance to both HB strains were associated with one chromosomal region of LG 5. However, the other QTL for resistance to the HB strains were on different linkage groups. No interaction was found between significant markers for leaf reactions to HB strains HB16 or 83-Sc2A. Except for a marker O12.900, the other markers included in the multiple regression model originated from the resistant parent Belneb RR1. The results obtained by the regression were similar to those obtained by interval mapping.

QTL FOR CBB Resistance. Continuous distributions of ratings for CBB (Xcp strain EK-11) leaf and pod reactions were observed (Fig. 2). Quantitative inheritance of reactions to Xcp strains has been reported previously (Arnaud-Santana et al., 1994; Coyne and Schuster, 1983).

Five chromosomal regions were significantly associated with resistance to leaf reactions of $X c p$ strain EK-11 $(P<0.05)$ based on single-factor ANOVA. However, only three of these markers were significant $(P<0.05)$ using stepwise regression. The markers W10.550, R20.1250, and Y4.1700, explained 44\%, 7\%, and $3 \%$ of the phenotypic variation for the trait, respectively (Table 2 ). The three markers together accounted for $54 \%$ of the total phenotypic variation. Two of four chromosomal regions significantly $(P<0.05)$ associated with pod resistance by ANOVA were significant in the multiple regression model. These two markers, W10.550 located in LG 10 and A10.1750 located in LG 2, explained $41 \%$ and $3 \%$, respectively, of the total phenotypic variation for the trait (Table 2). Interval mapping indicated that the most likely position for the QTL linked to W10.550 is about $8 \mathrm{cM}$ from W10.550 toward BC409SCAR/BC409.1250 locus. Markers, W10.550, R20.1250, A10.1750, and G17.400 were associated with both leaf and pod reactions. This suggests the presence of a common gene or gene cluster controlling reactions in both plant organs. Different and similar QTL controlling reactions of leaf and pod to $X c p$ have been reported (Jung et al., 1996; Miklas et al., 1996). A single QTL controlling leaf or pod reactions with small effects (13\% leaf, $13 \%$ pod) (Jung et al., 1996) and with large effects (60\% leaf, $44 \%$ pod) (Miklas et al., 1996) was reported previously. In another study, a single QTL accounted for $32 \%$ of the total phenotypic variation for CBB leaf resistance (Nodari et al., 1993b). These QTL with large effects may be valuable for use in marker assisted selection (MAS).

Previously, genetically independent CBB resistance QTL were associated with K19.450 (and closely linked markers) and BC409.1250 which were thought to be genetically unlinked (Jung et al., 1996; Jung et al., 1999). In addition, Jung et al. (1999) reported that the unmapped marker BC409.1250 was significantly associated with resistance to $X c p$ strains EK-11, DR-7, and Epif-IV in leaves and pods in four different bean populations. Markers linked to K19.450 were also associated consistently with CBB resistance QTL in three of four populations examined (Jung et al., 1999). Thus, results of these earlier QTL studies suggested strong evidence for two independent CBB resistance QTL that were not known to be linked on LG 10. Furthermore, the discovery of marker W10. 550 is very significant because it changes our understanding of the genetic structure of this trait and suggests a single locus that has a much greater phenotypic effect than the flanking loci that had been identified previously. Based on these results, marker W10.550 should be tested in additional populations and perhaps converted to a sequence specific PCR marker as was done for BC409.1250 (Jung et al., 1999).

All the markers significantly associated with CBB leaf and pod reactions by regression analysis were also the prominent markers detected by interval mapping. Significant interactions between markers associated with $\mathrm{CBB}$ leaf resistance were reported previously in a different cross (Jung et al., 1997). However, significant interactions were not found between marker loci significantly associated with resistance QTL in the present study.

LINKAGES AMONG LOCI FOR DISEASE RESISTANCE. Chromosomal regions associated with resistance to multiple pathogens were observed by Jung et al. (1996) and Miklas et al. (1996). Also, Nodari et al. (1993b) found a QTL for resistance to Xcp and for nodulation of Rhizobium tropici (Martinez-Romero) bacteria 
located in the same linkage group. In the present study, a chromosomal region for resistance to $\mathrm{CBB}$ in pods and HB strain 83$\mathrm{Sc} 2 \mathrm{~A}$ in leaves and for the $I$ gene including SCAR (SW13) were detected in LG 2. In addition, QTL for resistance to CBB and HB were located in LGs 9 and 10. However, the other QTL for reactions to these two pathogens appear to be dispersed throughout the bean genome. A putative association between the locus of the $I$ gene and resistance to HB African race 3 was noted previously (J.D. Taylor, Horticulture Research International, Wellesbourne, Warick, U.K., unpublished data). Ariyarathne (1997) identified HB strain 83-Sc2A as a race 7.

QTL for resistance to leaf and pod reactions to $X c p$ and leaf reactions to $\mathrm{HB}$ detected here should be investigated further for MAS. Some markers linked to a gene or QTL for leaf resistance to the two strains of the same pathogen or resistance in two plant organs, leaf and pod, for the same pathogen (CBB) were detected. In some cases where disease resistance genes are clustered, and the appropriate linkage phase is present between marker and gene loci, there is potential for simultaneous selection for different disease resistances using the same markers. The majority of the markers found originated from the resistant parent and were linked in coupling phase with QTL or major genes for disease resistance.

In conclusion, the map developed here includes markers linked with genes for resistance to two bacterial pathogens, and one virus pathogen causing important bean diseases. This study contributes additional information on the organization of the bean genome and on the genomic relationships of loci controlling resistance to pathogens causing $\mathrm{BCMV}, \mathrm{CBB}$, and $\mathrm{HB}$ in common bean.

\section{Literature Cited}

Adam-Bondon, A., M. Dron and M. Sevignac. 1994. A genetic map of common bean to localize specific resistance genes against anthracnose. Genome 37:915-924.

Andrus, C.F. 1948. A method of testing beans for resistance to bacterial blights. Phytopathology 38:757-759.

Ariyarathne, H.M. 1997. Pathogenic variation for the halo blight bacterium and mapping of loci for multiple diseases in common bean. $\mathrm{PhD}$ diss., Univ. Nebr., Lincoln.

Arnaud-Santana, E., D.P. Coyne, K.M. Eskridge, and A.K. Vidaver. 1994. Inheritance; low correlations of leaf, pod, and seed reactions to common blight disease in common beans; and implications for selection. J. Amer. Soc. Hort. Sci. 119:116-121.

Bassett, M.J. 1991. A revised linkage map of common bean. HortScience 26:834-836.

Coyne, D.P. and M.L. Schuster. 1975. Breeding and genetic studies of tolerance to several bean (Phaseolus vulgaris) bacterial pathogens. Euphytica 23:651-656.

Coyne, D.P. and M.L. Schuster. 1983. Genetics of and breeding for resistance to bacterial pathogens in vegetable crops. HortScience 18:30-36.

Drijfhout, E. 1978. Genetic interaction between Phaseolus vulgaris and bean common mosaic virus with implications for strain identification and breeding for resistance. Agr. Res. Rpt. 872. Centrl. Agr. Publ. Doc. Wageningen, The Netherlands.

Drijfhout, E. 1991. Bean common mosaic, p. 37-39. In: R. Hall (ed.). Compendium of bean diseases. Amer. Phytopathol. Soc., St. Paul, Minn.

Freyre R., P.W. Skroch, A.-F. Adam-Blondon, V. Geffroy, A. Shirmohamadali, W.C. Johnson, V. Llaca, R.O. Nodari, P.A. Pereira, S.-M. Tsai, J. Tohme, M. Dron, J. Nienhuis, and P. Gepts. 1998. Towards an integrated linkage map in common bean IV: Correlation among RFLP maps. Theor. Appl. Genet. 97:834-846.
Hagedorn, D.J. and R.E. Rand. 1977. Wisconsin (BBSR) 130 bean breeding line. HortScience 12:356.

Haley, S.D., L.K. Afanador, and J.D. Kelly. 1994. Identification and application of a random amplified polymorphic DNA marker for the $I$ gene (potyvirus resistance) in common bean. Phytopathology 84:157160.

Johns, M.A., P.W. Skroch, J. Nienhuis, P. Hinrichsen, G. Bascur, and C. Munoz-Schick. 1997. Gene pool classification of common bean landraces from Chile based on RAPD and morphological data. Crop Sci. 37:605-613.

Jung, G., D.P. Coyne, P.W. Skroch, J. Nienhuis, E. Arnaud-Santana, J. Bokosi, H.M. Ariyarathne, J.R. Steadman, J.S. Beaver, and S.M. Kaeppler. 1996. Molecular markers associated with plant architecture and resistance to common blight, web blight, and rust in common beans. J. Amer. Soc. Hort. Sci. 121:794-803.

Jung, G., P.W. Skroch, D.P. Coyne, J. Nienhuis, E. Arnaud-Santana, H.M. Ariyarathne, S.M. Kaeppler, and M.J. Bassett. 1997. Molecularmarker-based genetic analysis of tepary bean-derived common bacterial blight resistance in different developmental stages of common bean. J. Amer. Soc. Hort. Sci. 122:329-337.

Jung, G., P.W. Skroch, J. Nienhuis, D.P. Coyne, H.M. Ariyarathne, and E. Arnaud-Santana. 1999. Confirmation of QTL associated with common bacterial blight resistance in four different genetic backgrounds in common bean. Crop Sci. (in press).

King, E.O., M.K. Ward, and D.E. Raney. 1954. Two simple media for the demonstration of pyocyanin and fluorescein. J. Lab Clinical Med. 44: 301-307.

Kosambi, D.D. 1944. The estimation of map distance from recombination values. Ann. Eugenics 12:172-175.

Lander, E.S., and D. Botstein. 1989. Mapping Mendelian factors underlying quantitative traits using RFLP linkage maps. Genetics 121:185199.

Lander, E.S., P. Green, J. Abrahamson, A. Barlow, M.J. Daly, S.E. Lincon, and L. Newburge. 1987. Mapmaker: An interactive computer package for constructing primary genetic linkage maps of experimental and natural populations. Genomics 1:174-181.

Legard, D.E. and H.F. Schwartz. 1987. Sources and management of Pseudomonas syringae pv. phaseolicola and Pseudomonas syringae pv. syringae epiphytes on dry beans in Colorado. Phytopathology 77:1503-1509.

McKern, N.N., G.I. Mink, O.W. Barnett, A. Mishra, L.A. Whittaker, M.J. Silbernagel, C.W. Ward, and D.D. Shulka. 1992. Isolates of bean common mosaic virus comprising two distinct potyviruses. Phytopathology 82:923-929.

Melotto, M., L. Afanador, and J.D. Kelly. 1996. Development of a SCAR marker linked to the I gene in common bean. Genome 39:1216-1219. Miklas, P.N., E. Johnson, V. Stone, J.S. Beaver, C. Montoya, and M. Zapata. 1996. Selective mapping of QTL conditioning disease resistance in common bean. Crop Sci. 36:1344-1351.

Mink, G.I., C.W. Vetten, C.W. Ward, P. Berger, F. Morales, J.R. Myers, J.R. Silbernagel, and O.W. Barnett. 1994. Taxonomy and classification of legume infecting potyviruses. A proposal from the potyviridae Study Group of the Plant Virus Subcommittee of ICTV. Arch. Virology 139:2311-2315.

Nodari, R.O., S.M. Tsai, R.L. Gilbertson, and P. Gepts. 1993a. Toward an integrated linkage map of common bean. II. Development of RFLPbased linkage map. Theor. Appl. Genet. 85:513-520.

Nodari, R.O., S.M. Tsai, P. Guzman, R.L. Gilbertson, and P. Gepts. 1993b. Toward an integrated linkage map of common bean. III. Mapping genetic factors controlling host-bacteria interactions. Genetics 134:341-350.

Park, S.J. and B.N. Dhanvantari. 1994. Registration of common bean blight-resistant germplasm, HR45. Crop Sci. 34:548.

Saettler, A.W. 1989. Common bacterial blight, p. 261-283. In: H.F. Schwartz and M.A. Pastor-Corrales (eds.). Bean production problems in the tropics. CAB Intl., London.

Saettler, A.W. 1991. Halo blight, p. 30-31. In: R. Hall (ed.). Compendium of bean diseases. Amer. Phytopathol. Soc., St. Paul, Minn. 
SAS Institute Inc. 1982. User's guide: Statistics. SAS Inst. Inc., Cary, N.C.

Schuster, M.L. 1955. A method of testing resistance of beans to bacterial blights. Phytopathology 45:519-520.

Silva, L.O., S.P. Singh, and M.A. Pastor-Corrales. 1989. Inheritance of resistance to bacterial blight in common bean. Theor. Appl. Genet. 78:619-624.

Skroch, P.W. 1998. Random amplified polymorphic DNA based germplasm and genetic mapping studies in common bean. $\mathrm{PhD}$ diss., Univ. Wis., Madison.

Skroch, P.W. and J. Nienhuis. 1995. Qualitative and quantitative characterization of RAPD variation among snap bean (Phaseolus vulgaris) genotypes. Theor. Appl. Genet. 91:1078-1085.

Stavely, J.R., J.R. Steadman, D.P. Coyne, and D.T. Lindgren. 1989. Belneb rust resistant-1 and -2 Great Northern dry bean germplasm. HortScience 24:400-401.

Taylor, J.D., D.M. Teverson, and J.H.C. Davis. 1996. Sources of resistance to Pseudomonas syringae pv. phaseolicola races in Phaseolus vulgaris. Plant Pathol. 45:479-485.
Vallejos, C.E., C.D. Chase, and N.S. Sakiyama. 1992. A molecular marker-based linkage map of Phaseolus vulgaris L. Genetics 131:733740.

Vallejos, C.E., J. Nienhuis, and P.W. Skroch. 1999. Phaseolus vulgaris. The common bean: Integration of RFLP and RAPD based linkage maps. In: R.L. Phillips and I.K. Vasil (eds.). DNA based markers in plants. 2nd ed. Kluwer Academic Publishers, Dordrecht, The Netherlands (in press).

Velich, I., J. Szarka, and P.N. da. 1994. Biotic and abiotic stresses in the bean: I. Genetic background of complex resistance to bacterial diseases. Kertâzeti TudomÊny (Hort. Sci.) 26:49-53.

Young, J.M., D.W. Dye, J.F. Bradbury, C.G. Panagopoulos, and C.F. Robbs. 1978. A proposed nomenclature and classification for plant pathogenic bacteria. N.Z. J. Agr. Res. 21 (1): 153-177.

Yu, Z.H, R.E. Stall, and C.E. Vallejos. 1998. Detection of genes for resistance to common bacterial blight of beans. Crop. Sci.: 38:1290 1296.

Zaumeyer, W.J. and H.R. Thomas. 1957. A monographic study of bean diseases and methods for their control. USDA Agr. Tech. Bul. No. 868. 